\section{Cytotoxicity of Universal, Self-Etching and Etch-and-Rinse Adhesive Systems According to the Polymerization Time}

\author{
Silvia T. Elias ${ }^{1}$, Andressa F. dos Santos², Fernanda C.P. Garcia², Patrícia N.R. \\ Pereira $^{2}$, Leandro A. Hilgert², Yris M. Fonseca-Bazzo ${ }^{3}$, Eliete N. S. Guerra', \\ Ana Paula Dias Ribeiro ${ }^{2}$
}

\author{
'Laboratory of Oral Histopathology, \\ Department of Dentistry, School of \\ Health Sciences, UNB - University \\ of Brasilia, Brasilia, DF, Brazil \\ ${ }^{2}$ Department of Dentistry, School of \\ Health Sciences, UNB - University \\ of Brasilia, Brasilia, DF, Brazil \\ ${ }^{3}$ Department of Pharmaceutical \\ Sciences, School of Health \\ Sciences, UNB - University of \\ Brasilia, Brasilia, DF, Brazil
}

Correspondence: Prof. Dra. Ana Paula Dias Ribeiro, Campus Universitário Darcy Ribeiro - Asa Norte, 70910900 Brasilia, DF, Brasil. Tel: +5561-3107-1802. e-mail: apauladr@ yahoo.com.br; anaribeiro@unb.br

Key Words: cytotoxicity, dentin adhesive, polymerization time, fibroblasts.

\section{Introduction}

Adhesive systems are constantly being developed with elaborate and complex chemistry. Recently, some manufacturers released more versatile adhesive systems that include the "etch-and-rinse" and "self-etching" techniques, known as Universal or "Multi-mode" adhesive systems (1). The chemical formulation of adhesive systems generally comprises hydrophilic and hydrophobic bifunctional monomers, acidic monomers containing radicals derived from carboxylic or phosphoric acid, or even derived from organic acids or minerals as additives (2). In addition to these monomeric components, solvents (water, alcohol or acetone), aromatic amines, photoinitiators and filler particles are also present in the formulations. In these new universal systems, other components may be added to provide wider indications and applications, such as silane and chlorhexidine. These additional components may alter the biological behavior of the pulp-dentin complex if they are not incorporated in the polymer network, and may be released after polymerization and diffused through dentinal tubules (3). Therefore, these materials and the concept behind them are new, and scarce information is available in the literature regarding their clinical and biological performance (1).

A further factor directly related to the biological responses of the pulp to adhesive systems concerns monomer conversion into polymers, obtained by the polymerization technique $(4,5)$. Obtaining a polymer with optimized properties depends on parameters related to light intensity and spectral irradiance as well as polymerization time and application mode $(6,7)$. Ye et al. (6) evaluated the effect of light irradiance and source on the photopolymerization of three commercial dental adhesives by monitoring the double bond conversion as function of time during and after irradiation. These authors observed that the time for Single Bond with little solvent to reach the conversion plateau was about $20 \mathrm{~s}$, while the time for OneUp Bond F was about $25 \mathrm{~s}$ and for Adper Prompt as long as $40 \mathrm{~s}$, and they indicated that the time required to reach the conversion plateau for adhesive polymerization is a valuable information for the dental clinic (6).

All these parameters influence directly the degree of monomer conversion and consequently the release of residual monomers such as HEMA, BisGMA, TEGMA, usually considered as toxic substances that could cause harm or even cell death (8). Since the available adhesive systems 
are not able to hermetically seal the deep dentin (9), these residual monomers as well as other components of the adhesive systems, may penetrate through the dentinal tubules and reach the dental pulp chamber, causing irreversible damage to the specialized cell tissue.

Therefore, this in vitro study aimed to evaluate the direct cytotoxicity on L929 cell culture of the universal, self-etching and etch-and-rinse adhesive systems according to the polymerization time. The null hypotheses tested were that the polymerization time and the adhesive system would not influence the cytotoxicity of adhesive systems on the fibroblast culture.

\section{Material and Methods}

\section{Cell Culture and Preparation of Specimens}

The fibroblast cell line L929 was grown as monolayers in a mixture of Dulbecco's modified Eagle medium (DMEM) supplemented with 10\% fetal bovine serum (FBS) and 1\% antibiotics (penicillin-streptomycin). Cells were maintained at $37^{\circ} \mathrm{C}$ and $5 \%$ of $\mathrm{CO}_{2}$ in a humidified incubator. For all the experiments, cells were detached with trypsin (0.25\%)/EDTA $(1 \mathrm{mM})$ solution. All cell culture reagents were purchased from Sigma-Aldrich (Sigma Chemical Co., St. Louis, MO, USA). The cell line used is described in the ATCC (American Type Culture Collection).

For preparation of specimens, filter paper disks of 6 $\mathrm{mm}$ diameter were made and sterilized. The discs were impregnated with $5 \mu \mathrm{L}$ of each adhesive. Only the adhesive bottle was used: A1 (Adper ${ }^{\mathrm{TM}}$ Single Bond 2), A2 (Adper ${ }^{\mathrm{TM}}$ Scotchbond ${ }^{\text {TM }}$ Multi-purpose), A3 (Clearfil ${ }^{\text {TM }}$ SE Bond) and A4 (Scothbond ${ }^{\mathrm{TM}}$ Universal). Table 1 presents the manufacturer's information, classification and components of the dental adhesives tested in this study. Then, the impregnated discs were polymerized for different times: 10,20 or 40 s continuously, using a halogen light unit Demetron ${ }^{\circledR}$ LC $^{\text {TM }}$ (Kerr Company, Orange, CA USA) with light intensity $\geq 600 \mathrm{~mW} / \mathrm{cm}^{2}$. The curing lamp tip was maintained $2 \mathrm{~mm}$ from the disks using a plastic holder at this fixed distance. Subsequently, the disks were stored in microtubes containing $500 \mu \mathrm{L}$ of culture medium (DMEM without FBS) during two different storage periods ( $24 \mathrm{~h}$ or 7 days) at $37{ }^{\circ} \mathrm{C}$ and $5 \%$ of $\mathrm{CO}_{2}$. For the negative control, disks without dental adhesives were immersed in DMEM.

\section{Adhesive Cytotoxicity Assay (MTT Assay)}

Cells were seeded at the density of $5 \times 10^{3}$ cells/well in 96-well plates overnight and then treated with $100 \mu \mathrm{L}$ of eluate (culture medium + components leached from the adhesives). For negative control, cells were treated only with the culture medium. Following $24 \mathrm{~h}$ of treatment, cell metabolism was assessed by MTT and the absorbance was measured at $570 \mathrm{~nm}$ in a Beckman Counter reader.
This test assesses the ability of mitochondrial enzymes of the treated cells to convert tetrazolium salts into formazan crystals. The percentage of viable cells was obtained by comparing them with the absorbance values obtained in the negative control group. All experiments were carried out at least three separate times and were performed in triplicate. Adhesives A2 and A4 were selected to perform the latter assays.

\section{Scanning Electron Microscopy (SEM) Analysis}

Cells were seeded at $6 \times 10^{4} \mathrm{cell} /$ well in a 24-well plate that had been previously prepared with a $13 \mathrm{~mm}$ coverslip placed on the bottom. Then the cells were treated with the eluates obtained from adhesives A2 and A4, which were polymerized for 20 or $40 \mathrm{~s}$ and stored for $24 \mathrm{~h}$ or 7 days. After the treatment, cells that remained adhered to the glass substrate were fixed in $1 \mathrm{~mL}$ of $2.5 \%$ buffered glutaraldehyde for $24 \mathrm{~h}$ and dehydrated in a series of increasing ethanol concentrations (30,50, 70, 95 and 100\%) followed by gold bath. Finally, cell morphology of the adhered L929 fibroblasts were examined with a scanning electron microscope (JEOL, JSM 7001F, Japan).

\section{Flow Cytometry Analysis}

The specimens were prepared as previously described. Cells were plated in 12 -well plates at $25 \times 10^{4}$ cells/per well and treated with eluates of the respective adhesives. After $24 \mathrm{~h}$ of treatment, cells and supernatant were collected, centrifuged at 2,000 rpm for $5 \mathrm{~min}$, resuspended in 500 $\mu \mathrm{L}$ of cold PBS (phosphate saline buffer). Next, $50 \mu \mathrm{L}$ of propidium iodide $(20 \mu \mathrm{L} / \mathrm{mL})$ were added to the cell suspension. Approximately 10,000 cells were analyzed from each sample. Flow cytometric analysis was performed by Partec Cyflow cytometer in FL2 and FL3 channels. Percentage of dead cells was calculated by comparison to the control sample.

\section{High-Performance Liquid Chromatography (HPLC) Analyses}

Adhesives samples stored in artificial saliva for $24 \mathrm{~h}$ or 7 days were analyzed using the LaChrom Elite HPLC system (Hitachi, Tokyo, Japan) liquid chromatograph equipped with L2130 pump, L2200 auto-sampler. The 2300 column oven was set at $25{ }^{\circ} \mathrm{C}$ and the L2455 DAD detector (Hitachi) was used. The detector was set at $220 \mathrm{~nm}$ and $300 \mathrm{~nm}$. Separation was performed by Purospher Star reverse phase C18e column (5 $\mu \mathrm{m}, 150 \mathrm{~mm} \times 4.6 \mathrm{~mm}$ i.d.) in combination with an appropriate guard column $(4 \times 4 ; 5 \mu \mathrm{m}$ particle size) (Merck, Germany). The mobile phase was a linear solvent gradient system consisting of $\mathrm{H}_{2} \mathrm{O}(\mathrm{A})$ and $\mathrm{CH}_{3} \mathrm{CN}$ (B), at a flow rate of $0.8 \mathrm{~mL} / \mathrm{min}$. The gradient was $85 \%$ (A) and 15\% (B) at $0 \mathrm{~min}, 50 \%(\mathrm{~A})$ and $50 \%$ (B) at $25 \mathrm{~min}$, 
and $40 \%(\mathrm{~A})$ and $60 \%(\mathrm{~B})$ at $40 \mathrm{~min}$. Data acquisition was performed using EZChrom Elite software version 3.3.2 SP1 (Scientific Software Inc. Skokie, IL, USA). The compounds in the samples were characterized according to their UV-vis spectra and identified by their retention times in comparison with those of commercial standards.

\section{Data Analysis}

The means obtained from the MTT assay were calculated for the groups and transformed into percentages, which represented the inhibitory effect of the cell mitochondrial activity by the eluates. The negative control (culture medium) was defined as having 100\% cell metabolism. Statistical analyses were performed using SPSS version
21 and applying Kruskal-Wallis and Mann-Whitney nonparametric tests. A threshold of $p<0.05$ was defined as statistically significant.

\section{Results}

\section{Cytotoxic Effect of Adhesives on Cell Metabolism}

Treatment with the different adhesives provided variable responses as regards cell metabolism. Tables 2 and 3 show that treatment with the four adhesives resulted in cell death average of 33 to $51 \%$, demonstrating a moderate cytotoxic effect of the tested systems. There was no statistical difference among the light-curing times for all tested dental adhesives $(10,20$ or $40 \mathrm{~s})$ and for all storage periods ( $24 \mathrm{~h}$ or 7 days), showing that the increase

Table 1. Test materials, classification and principal components

\begin{tabular}{|c|c|c|c|c|}
\hline Dentin adhesive & Lot number & Manufacturer & Classification & Components \\
\hline $\begin{array}{l}\text { Adper }^{\mathrm{TM}} \text { Single } \\
\text { Bond } 2\end{array}$ & 9YNBR & $\begin{array}{l}\text { 3M/ESPE Dental } \\
\text { Products, St. } \\
\text { Paul, MN, USA }\end{array}$ & $\begin{array}{l}\text { Two-step etch } \\
\text { and rinse }\end{array}$ & $\begin{array}{l}\text { Bis-GMA, HEMA, polyacrylic acid, poly(itaconic acid), } \\
\text { water, ethanol, dl-camphorquinone, silica (10\% wt) }\end{array}$ \\
\hline
\end{tabular}

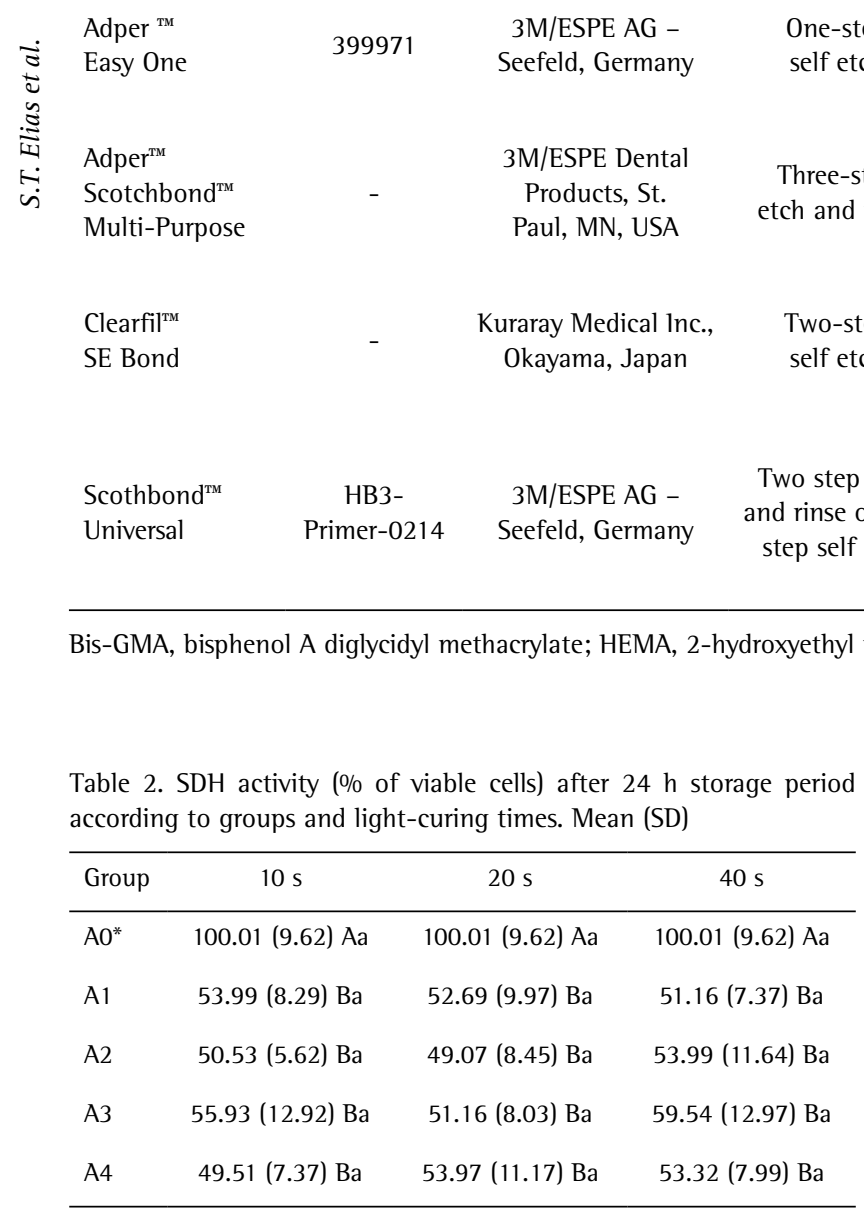

*Control. Different uppercase letters indicate statistically significant difference inside the column (between groups). Different lowercase letters indicate statistically significant difference inside the row (between light-curing times). Kruskal-Wallis, Mann-Whitney, $\mathrm{p}<0.05$.
Table 3. SDH activity (\% of viable cells) after 7 days storage period according to groups and light-curing times. Mean (SD)

\begin{tabular}{lccc}
\hline Group & $10 \mathrm{~s}$ & $20 \mathrm{~s}$ & $40 \mathrm{~s}$ \\
\hline $\mathrm{A} 0$ & $100.00(11.26) \mathrm{Aa}$ & $100.00(11.26) \mathrm{Aa}$ & $100.00(11.26) \mathrm{Aa}$ \\
$\mathrm{A} 1$ & $56.26(9.95) \mathrm{Ba}$ & $65.18(17.08) \mathrm{ABa}$ & $66.90(11.00) \mathrm{ABa}$ \\
$\mathrm{A} 2$ & $51.23(6.40) \mathrm{Ba}$ & $55.99(7.68) \mathrm{Ba}$ & $55.74(8.21) \mathrm{BCa}$ \\
A3 & $53.12(5.72) \mathrm{Ba}$ & $52.99(3.95) \mathrm{Ba}$ & $52.27(2.88) \mathrm{BCa}$ \\
A4 & $52.62(10.63) \mathrm{Ba}$ & $54.28(12.13) \mathrm{Ba}$ & $48.87(3.64) \mathrm{Ca}$ \\
\hline
\end{tabular}

${ }^{*}$ Control. Different uppercase letters indicate statistically significant difference inside the column (between groups). Different lowercase letters indicate statistically significant difference inside the row (between light-curing times). Kruskal-Wallis, Mann-Whitney, $\mathrm{p}<0.05$. 
of time exposure to light was not sufficient to reduce the toxicity of these adhesives.

For the $24 \mathrm{~h}$ storage period, there was a significant difference in the percentage of viable cells for all experimental groups (A1, A2, A3 and A4) compared with the control group (A0). Moreover, these groups were not statistically different among them ( $p>0.05)$ and presented a reduction of cell metabolism ranging from 40 to $50 \%$.

The results for the 7 days storage period (Table 3 ) are similar to those observed for the $24 \mathrm{~h}$ period, and the reduction of cell metabolism observed in the experimental groups ranged from 33 to 51\%. After $10 \mathrm{~s}$ of lightcuring, the cytotoxic effect of adhesives was statistically different from the control group $(p<0.05)$. After 20 or 40 $s$ polymerization, A1 was not different from the control group ( $p>0.05$ ) and for the $40 \mathrm{~s}, \mathrm{~A} 1$ differed significantly from $A 4(p<0.05)$.

\section{Cell Morphology Analysis by SEM}

Figure $1(A-F)$ presents a panel of SEM micrographs of
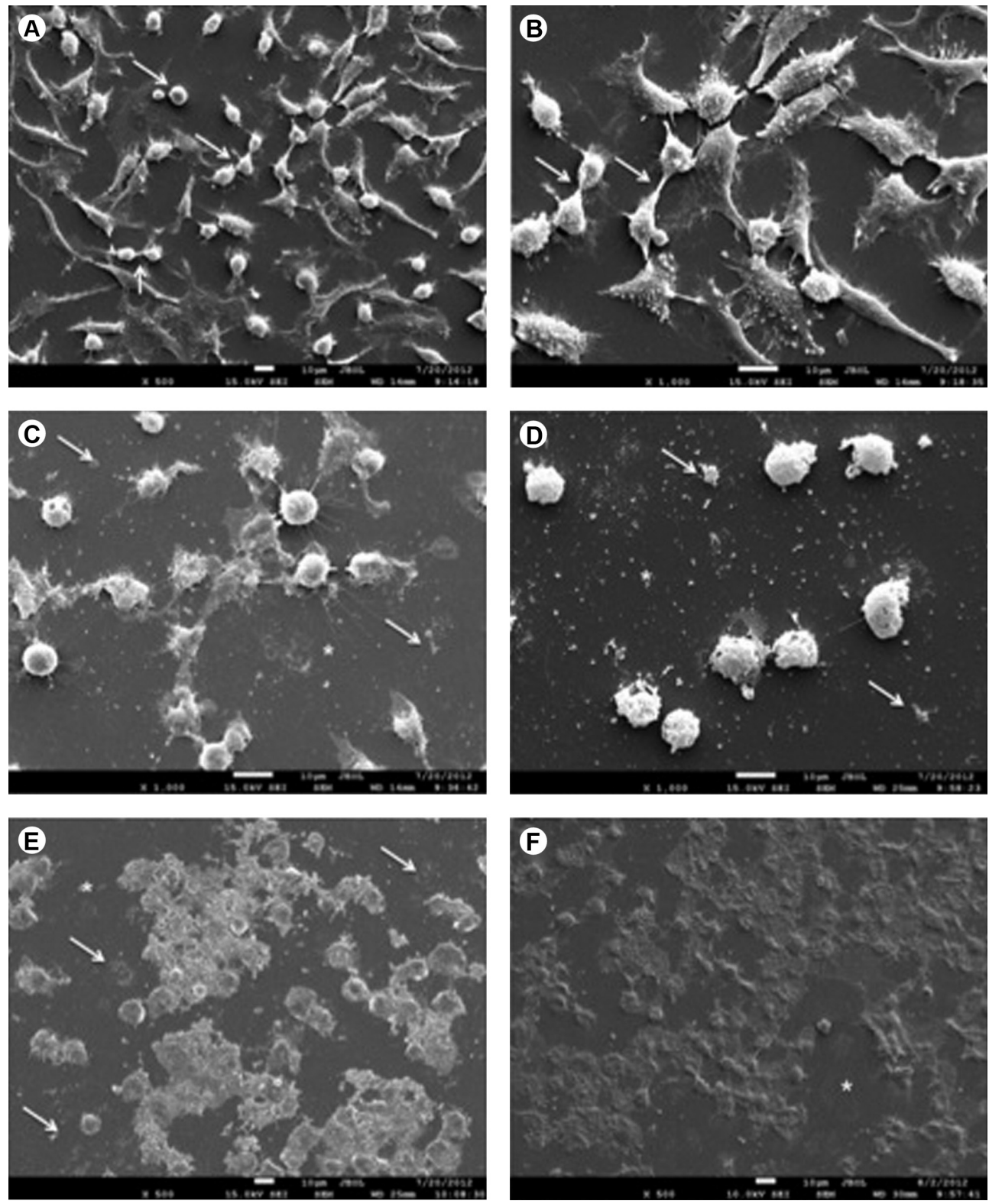

Figure 1. Panel of SEM micrographs of 2929 fibroblasts. A: Negative control group: A large number of L929 fibroblasts maay be observed and numerous mitoses are occurring (white arrows). SEM, $\times 500$. B: Negative control group: The spindle-shaped cells present fine cytoplasmic processes that seem to be keeping the cells attached to the glass substrate. SEM, $\times 1000$. C: A2 eluate $(24 \mathrm{~h})$ : fibroblasts exhibit an altered morphology with round shape and small size. SEM, $\times 1000$. D: A2 eluate (7 days): Presence of cytoplasmic membrane rests of dead cells (white arrows). SEM, $\times 1000$. E: A4 eluate (24 h): fibroblasts exhibit an altered morphology with ill-defined cell limits, suggesting cell necrosis. Presence of cytoplasmic membrane (white arrows). SEM, $\times 1000$. F: A4 eluate (7 days): the morphological alterations of the 2929 fibroblasts observed in $24-\mathrm{h}$ storage period were maintained with presence of disrupted membrane (white arrows). SEM, ×1000. Asterisk identifies areas free of cells, suggesting cell death. 
the $\mathbf{2 9 2 9}$ fibroblasts after contact with adhesive eluates for $24 \mathrm{~h}$. For the negative control group (exposed only to culture medium), it may be observed that the adhered cells to the glass substrate exhibited a spindle-shaped appearance with few cytoplasmic processes originating from the membrane (Figs. 1A, B). Moreover, cell mitoses (white arrows) are also present. For A2 eluates of $24 \mathrm{~h}$ or 7 days, may be observed cells with a round shape and small size. Both characteristics are similar to cells in apoptosis process (Figs. 1C, D). While for A4 eluates, no cell limits can be identified suggesting membrane disruption, which characterizes cell necrosis (Figs. 1E, F). Moreover, rests of the cytoplasmic membrane of dead cells identified by white arrows were observed for both adhesive systems (Figs. 1C-F), and areas free of cells were also present (asterisks), suggesting that the effect of the adhesive eluate was enough to cause cell death and their release from the glass substrate.

\section{Flow Cytometry Analysis}

Flow cytometry with propidium iodide (PI) confirmed that the treatment with dental adhesives could induce death in $\mathbf{L 9 2 9}$ cells. All the tested adhesives showed moderate to severe toxicity in the cell engender rates of cells stained with PI (Fig. 2).

A larger number of necrotic cells was found for A2 light-cured for $40 \mathrm{~s}$ in the 7 day storage period (5 times more compared with control). However, the same treatment in the $24 \mathrm{~h}$ storage period resulted in a lower rate of dead cells (1.9 compared to control). Treatment with A4 presented cell death rates ranging from 47.46 to $59.05 \%$ (nearly 4 times compared with control). The experiments were performed 3 times and aimed to provide qualitative

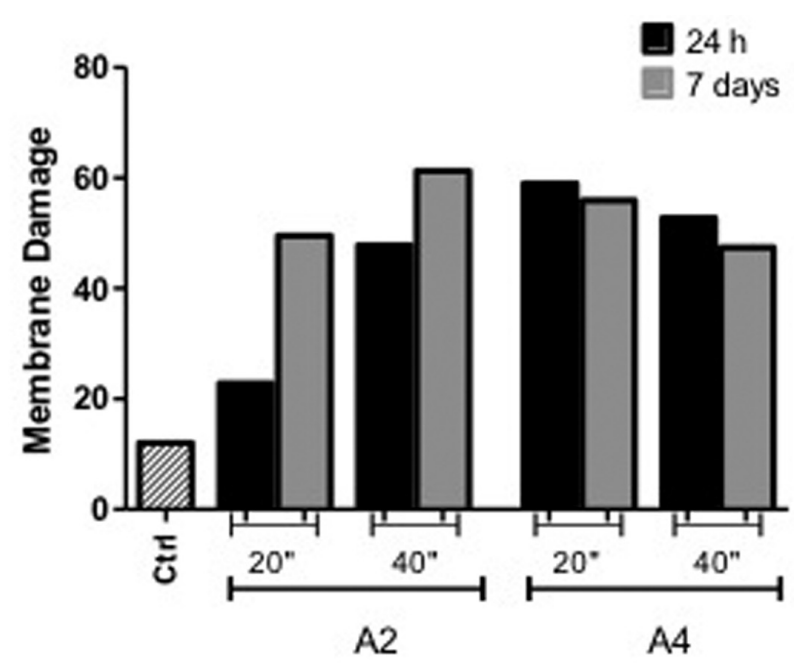

Figure 2. Bar graph representative of the results obtained from flow cytometry with propidium iodide showing the percentage of cytoplasmatic membrane damage for A0, A2 and A4 groups. data regarding the possible membrane damage caused by components released from polymerized adhesives.

\section{HPLC analyses}

The chromatographic profile of the different adhesive samples was similar in all cases, although different scales were used to observe the peaks. HEMA, BisGMA and TEGMA residues were not found in all samples. Therefore, the peaks found may represent incomplete polymerization products of these compounds. In the A2 and A4 samples, in the storage times of $24 \mathrm{~h}$ or 7 days, a peak with retention time in 29.3 min and UV spectra similar to BISGMA was found, which may represent a compound from BISGMA degradation or incomplete polymerization (Fig. 3).

\section{Discussion}

The present study partially rejects the proposed null hypotheses, as the polymerization time did not affect the direct cytotoxicity, while the type of adhesive system partially influenced the fibroblast metabolism. The L929 cell line has been usually employed to evaluate the direct toxicity of monomer-based materials as well as biomaterial behavior (10). The L929 fibroblasts represent an established and immortalized cell line that allows the investigation of factors directly related to adhesive systems and polymerization time, excluding bias from the donor cell.

In the present study, all the evaluated adhesive systems presented mild to moderate toxicity, according to ISO norms 10993-5:2009. The reduction of cell metabolism was around 43-51\% when compared with the control group (A0). These results are consistent with previous studies that evaluated the toxicity of different commercial or experimental adhesive systems $(11,12)$. Bianchi et al. (12) evaluated the toxicity of experimental adhesive systems with different degrees of hydrophilicity on odontoblast cell culture. The authors observed a significant reduction of cell metabolism ranging from 0.2 to $65.7 \%$ after $24 \mathrm{~h}$ of contact with the eluate obtained from filter paper discs impregnated with $10 \mu \mathrm{L}$ of light-cured adhesive (12). In another study that evaluated the indirect toxicity of commercial adhesive systems with a dentin barrier interposition, a reduction of over $50 \%$ in macrophage metabolism was observed after 24,48 and $72 \mathrm{~h}$ of contact with the adhesives (4).

The absence of a dentin barrier represents a limitation of the present study, as it is well known that its presence reduces the adhesive's diffusion and consequent toxicity. Moreover, the acidic monomers are gradually buffered by the mineral content of the tooth substrate loosing their ability to further etch dentin and reduce the $\mathrm{pH}$ of experimental eluates. These acids bond ionically to calcium of hydroxyapatite (Hap) releasing phosphate $\left(\mathrm{PO}_{4}{ }^{3-}\right)$ and hydroxide $\left(\mathrm{OH}^{-}\right)$ions from Hap into the own solution, so 
that the surface remains electro-neutral. The stability of the formed calcium salt will depend directly on the type of used acid monomer. While 10-methacryloyloxydecyl dihydrogen phosphate (10-MDP) and polyalkenoic acids will form a stable calcium salt, the phosphoric and maleic acid will readily de-bond (13). In addition, when using dentin barrier, the complete technique may be evaluated. Therefore, the differences between the adhesives systems (etch and rinse and self-etch) will stand as they deal differently with the dentin, while the first removes the smear layer and smear plug, the last one incorporates and modifies them (13).

Regarding the polymerization time, the increase of this variable to $40 \mathrm{~s}$ did not reduce the toxicity of the adhesive systems compared with $10 \mathrm{~s}$ and $20 \mathrm{~s}$. Aranha et al. (14) found that reduction of the polymerization time to $15 \mathrm{~s}$

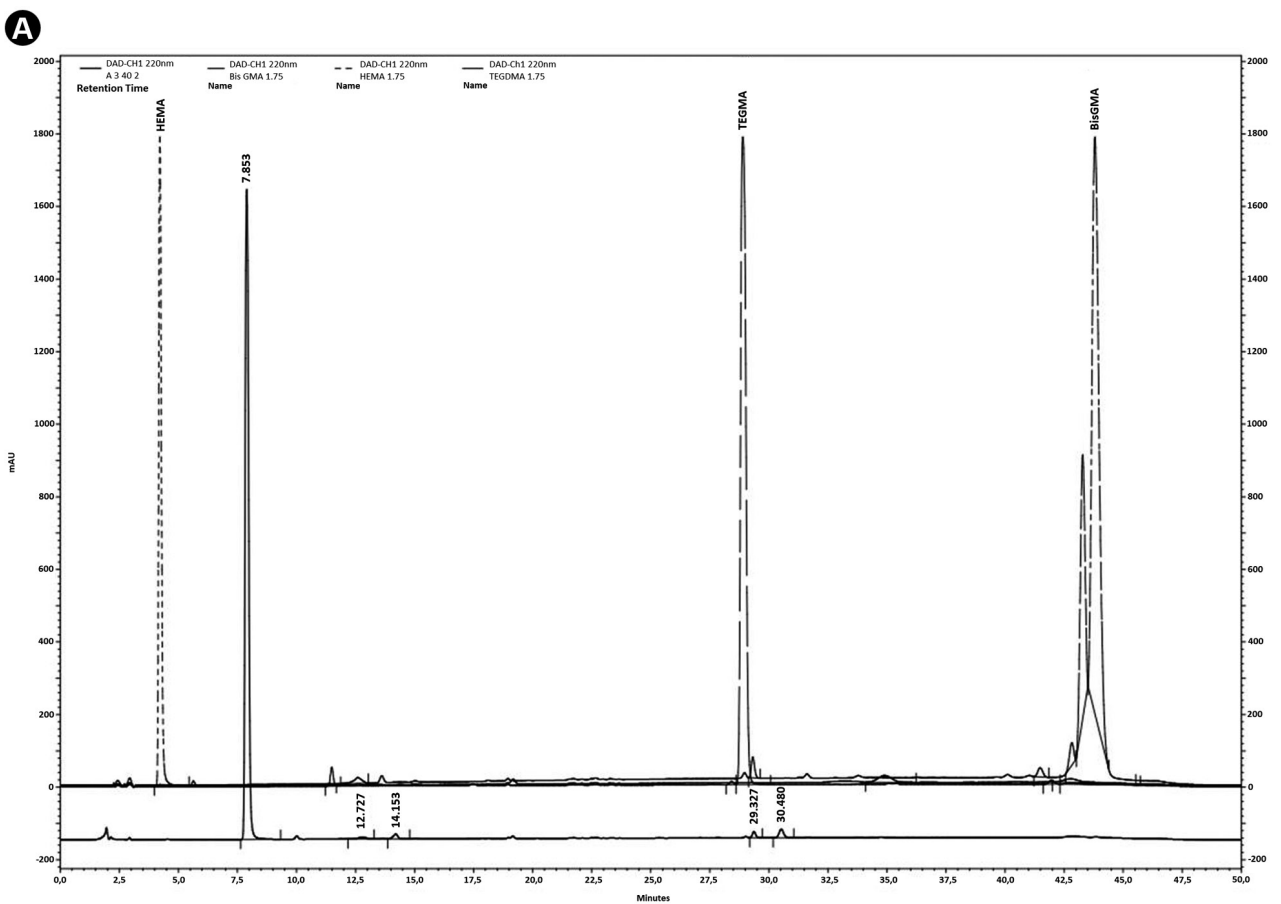

B

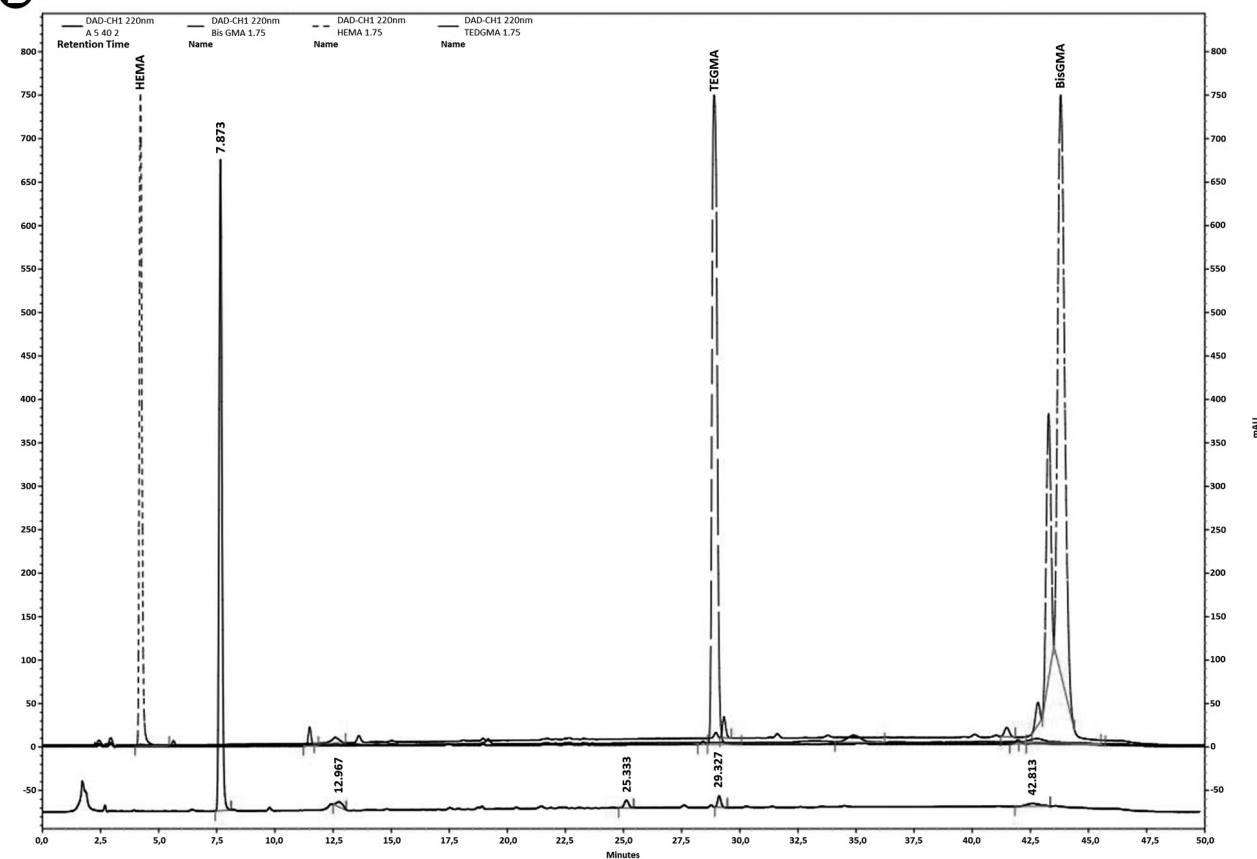

Figure 3. HPLC/DAD chromatogram of the different adhesive samples reported at $280 \mathrm{~nm}$, (A) A2 and (B) A4 in the 7-day storage times. 
or its increase to $45 \mathrm{~s}$ compared with the time indicated by the manufacturer ( $30 \mathrm{~s}$ ) did not alter the toxicity found for resin-modified glass ionomer cements in contact with odontoblast-like cells. The experimental conditions for in vitro studies can be strictly controlled, allowing the observation of the minimum thickness of adhesive to be polymerized, perfectly smooth prepared adhesion surface, uniform and minimum distance of the curing lamp tip, frequent irradiance measurement of the devices and control of dentin moisture. Therefore, for these studies, it is possible to observe that the increase of polymerization time does not result in a reduction of the toxicity of these materials, since $10 \mathrm{~s}$ is enough to provide a great monomer conversion in ideal conditions (14). Furthermore, it is known that there is a limit to the monomer conversion rate, which in these ideal conditions could probably be achieved more easily, since the longer polymerization times would not result in increased monomer conversion. It was observed in a recent study that the toxicity of experimental adhesive systems when polymerized for $10 \mathrm{~s}$ was not affected by different degrees of hydrophilicity, not even by the degree of conversion of the monomers (12).

Another point related to polymerization time is cell culture viability and reported that these agents are able to induce oxidative stress resulting in DNA damage, producing intracellular reactive oxygen species (ROS) and consequently inducing cell death $(15,16)$. A recent study has shown that camphorquinone irradiated or not induced cell apoptosis preceded a rise in the concentration of ROS. Although it is expected that longer periods of irradiation may consume more promoters, in the present study there was no difference in adhesive systems toxicity regarding the polymerization time (16). Therefore, it may be argued that the methodological conditions of the present study certainly favor the polymerization of the adhesive systems even for the minimum evaluated time (10 s), even when the manufacturers' instructions suggest longer periods. Moreover, the presence of polymerization promoters and consequently their possible interference in the cytotoxicity was not observed.

The toxicity of the adhesive systems observed in the present study resulted from the different chemical compositions of the adhesive component, since only this bottle was used. The complete technique was not evaluated, which could have included the acid etching or the primer step. It might be expected that the adhesive component from the 3-step etch-and-rinse adhesive technique compared to the 2-step self-etching material could be more toxic due to the higher amount of hydrophobic monomers. Moreover, the presence of acidic methacrylates in self-etch adhesives could also cause the reduction of cell culture medium $\mathrm{pH}$ resulting in cell damage. However, as shown by $\mathrm{MTT}$ results, all the tested adhesives presented mild to moderate toxicity that was directly related to presence of residual monomers in the eluates.

The ability of light-cured adhesive systems to release components in aqueous media due to hydrolytic degradation has been previously reported in the literature. Among the most commonly found residual monomers in eluates are HEMA and Bis-GMA, which are components of all the adhesive systems evaluated in this study. The ability of these monomers to alter cellular functions and induce oxidative stress leading to cell death characterized them as environmental stressors (8). Some studies demonstrated the potential of HEMA to induce apoptosis and genotoxic effects as a result of its role for inducing DNA strand breaks (8). This monomer is also related to the inhibition of inflammatory cytokine release of the host responses when challenged by LPS (17). Bis-GMA is also considered cytotoxic with an ability to alter the cell cycle and induce oxidative stress leading to apoptosis and necrosis in a concentration-dependent manner $(18,19)$. In the study conducted by Chang et al. (18), the concentration of 0.1 $\mathrm{mM}$ Bis-GMA reduced the metabolism of pulp cells by $50 \%$, similar to the present study. Thus, it may be speculated that the reduction of fibroblast metabolism observed for all evaluated adhesive systems is directly related to the presence of residual monomers in the eluate.

The HPLC results showed the presence of peaks close to the standard monomers, especially HEMA and BisGMA. It is known that in an aqueous environment, these monomers can be organized differently, as dimers or trimers, which modifies their retention time on the column. Some parameters influence directly the results obtained by HPLC, such as the initial amount of polymerized adhesive as well as the time and storage solution for obtaining eluate. Normally, in studies aiming to evaluate only the quantity of residual monomers, standardized specimens with an 8 $\mathrm{mm}$ diameter and $1 \mathrm{~mm}$ high are produced in conformity with ISO standards. In the present study was used filter paper and $5 \mu \mathrm{L}$ of adhesive, a volume that was sufficient to reduce by $50 \%$ the cellular metabolism when tested directly. Probably larger amounts of adhesive could lead to intense cell damage preventing the observation of the differences between the adhesive systems. Moreover, the storage time for obtaining the eluate was 7 days, considered to be enough time for saturation of the monomers of the adhesive systems (25). According to Örtengren et al. (21), a period of 7 to 60 days was required for the saturation of composites and, therefore, shorter periods would be 
enough for adhesive systems. Finally, the third parameter, storage medium, interferes directly on the type of monomer to be released. Hydrophilic monomers such as HEMA are more easily released in an aqueous solution due to their low molecular weight and chemical structure, which contains a hydroxyl with affinity to hydrogen bonding (20). Hydrophobic monomers, such as Bis-GMA, have high molecular weight and their chemical structure gives them characteristics such as high viscosity, low volatility, low polymerization shrinkage, resulting in more rigid resins with lower susceptibility to hydrolytic media (20). Thus, the storage in artificial saliva, as used in the present study, provides an increased release of hydrophilic components such as HEMA, which was evidenced by the presence of the highest peak near to its standard. However, a peak close to the Bis-GMA standard could be also seen, confirming the presence of this monomer in the eluate and justifying its cytotoxic contribution to cell metabolism reduction.

In addition to the monomers, adhesive systems also include other components that may contribute to their toxicity. This is particularly the case of the universal systems in which the components enable them to act as "self-etching" and "etch-and-rinse". The evaluated universal adhesive system contained silane, toluene, acrylic copolymer and other components that may enhance its direct toxic properties. Silane was included in the formulation to allow the adhesive system to be applied directly on the prosthetic crown eliminating the need to apply it separately. Little is known about the toxicity of this compound when incorporated into the adhesive system, since it will be part of the hybrid layer and in close contact with the pulp-dentin complex. Toluene acts as a solvent and its toxicity is well known. Therefore, the toxicity of this adhesive may have been influenced by the above-mentioned components that are not found in other adhesive systems.

The cell damage observed was not limited to the mitochondrial activity reduction, as assessed with MTT assay. Both flow cytometry and SEM micrographs revealed the ability of the evaluated adhesive systems to harm cell membrane, alter the morphology and reduce the number of adhered cells. The images obtained by SEM revealed substantial morphological cell changes for the groups exposed to the experimental eluates. These cells showed reduced size and rounded shape. These characteristics are compatible with cell death by apoptosis and were more pronounced for group A2. For A4, were observed non-delimited cells, suggesting cytoplasmatic membrane rupture, which represents a characteristic of necrotic cell death. For both groups, presence of cellular debris and areas with no cells were observed, which confirms the detachment of cells and consequent cell death.
The cell death caused by adhesive systems is directly related to the type and quantity of released monomer. The free residual monomers are capable of changing the cellular microenvironment by oxidative stress, since they are able to induce formation of reactive oxygen species (ROS) and reduce the quantity of antioxidants such as glutathione, leading to oxidative imbalance (8). The increase in ROS levels acts as a signal for the activation of pathways directly related to the control of cell death by antioxidant genes and proteins. According to Spagnuolo et al. $(22,23)$, the increase in ROS levels in fibroblasts caused by HEMA caused activation of NF-kB, which is a cellular mechanism that acts against cell death induced by monomers. The presence of NF-kB inhibitor resulted in a significant increase in the number of apoptotic cells after contact with HEMA, which proves the importance of activating this pathway for protection against apoptosis in the presence of HEMA (22). For Bis-GMA, Li et al. (19) showed that both types of cell death could be identified in the presence of this monomer. The determinant factor of the death was the monomer concentration, given that low concentrations of Bis-GMA induced apoptosis, while high concentrations induced death by necrosis or late apoptosis (19). According to the flow cytometry results, both A2 and A4 eluates were capable of causing irreversible damage to the cytoplasmic membrane of the fibroblasts, since propidium iodide $(\mathrm{PI})$ is a nuclear marker penetrating exclusively cells that have a damaged cellular membrane. For both adhesives, PI staining showed up in around 50\% of cells, similar to the result in the MTT assay. The results of flow cytometry for A4 showed that most treated cells exhibited membrane lesion, as observed in SEM, indicating cell death by necrosis or late apoptosis. Furthermore, since no annexin staining was performed, it is possible to suggest that cells initiating apoptosis could be present as observed in SEM and were more prevalent for group A2.

As previously demonstrated in the literature, no adhesive system should be applied directly on the pulp tissue $(24,25)$, since this would result in an intense and persistent inflammatory reaction. Moreover, the importance of dentin in neutralizing the $\mathrm{pH}$ of self-etching adhesive systems is well known (13). Thus, an adequate dentin barrier prevents or even reduces the amount of monomers and other components capable of causing damage to the pulp-dentin complex and still participate in the chemical reaction of adhesive systems, assisting in the reversion to a favorable $\mathrm{pH}$. Future in vitro studies with the presence of the dentin barrier are required to investigate the toxic potential of these new adhesive systems applying different techniques, whether self-etching or conventional. Despite methodological limitations, this in vitro study highlights that although the universal adhesive system presents a 
more complex composition, its biological response was not more toxic when compared with other systems, even when the shortest polymerization time was tested in cell culture.

\section{Resumo}

0 presente estudo in vitro avaliou a citotoxicidade direta dos sistemas adesivos convencionais, autocondicionantes e universais de acordo com o tempo de polimerização em cultura de fibroblastos. Discos de papel foram impregnados com adesivos e fotoativados (10, 20 e $40 \mathrm{~s}$ ). 0 s discos foram posteriormente imersos em meio de cultura para obtenção dos eluatos dos grupos experimentais (A1-Single Bond 2; A2-Scotchbond Multi-purpose; A3-Clearfil SE Bond; A4 Scotchbond Universal). Para o controle negativo, os discos de papel foram imersos somente em meio de cultura. Após $24 \mathrm{~h}$ ou 7 dias, o eluato obtido foi aplicado na cultura de fibroblastos. 0 metabolismo celular, morfologia, dano de membrana e presença de monômeros residuais foram avaliados por teste de MTT, MEV, citometria de fluxo e HPLC, respectivamente. Os dados foram analisados estatisticamente por Kruskal-Wallis e Mann-Whitney. Todos os sistemas adesivos reduziram significativamente o metabolismo celular em 33 a $51 \%$ quando comparados ao grupo controle, independente do tempo de polimerização, período de armazenamento e tipo de sistema adesivo., 0 eluato do adesivos causou ainda intensas alterações morfológicas e danos à membrana celular. A toxicidade foi diretamente relacionada à presença de monômeros residuais nos eluatos experimentais. Monômeros residuais e componentes adicionais dos sistemas adesivos foram capazes de reduzir a atividade mitocondrial, causar alterações morfológicas e danos à membrana citoplasmática de fibroblastos, independente do tempo de polimerização. Esse estudo evidencia que apesar de uma composição mais complexa do sistema adesivo universal, sua resposta biológica não

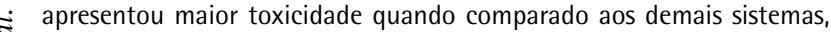
mesmo no menor tempo de polimerização quando testados em cultura celular.

\section{Acknowledgements}

The authors would like to acknowledge the Biology Institute of University of Brasilia for the assistance with the SEM and flow cytometry analyses. The adhesive systems used in this study were generously donated by 3M/ESPE Dental Products (St. Paul, MN, USA) and Kuraray America Inc. (New York, NY, USA).

\section{References}

1. Hanabusa M, Mine A, Kuboki T, Momoi Y, Van Ende A, Van Meerbeek B. Bonding effectiveness of a new 'multi-mode' adhesive to enamel and dentine. J Dent 2012;40:475-484.

2. Tay FR, Pashley DH. Aggressiveness of contemporary self-etching systems. I: Depth of penetration beyond dentin smear layers. Dent Mater 2001;17:296-308.

3. Lessa FC, Aranha AM, Nogueira I, Giro EM, Hebling J, Costa CA. Toxicity of chlorhexidine on odontoblast-like cells. J Appl Oral Sci 2010;18:5058.

4. Porto I, Oliveira D, Raele R, Ribas Ketlin, Montes M, De Castro C. Cytotoxicity of current adhesive systems: In vitro testing on cell cultures of primary murine macrophages. Dent Mater 2011;27:221228.

5. Sigusch BW, Pflaum T, Völpel A, Gretsch K, Hoy S, Watts DC, et al.. Resin-composite cytotoxicity varies with shade and irradiance. Dent Mater 2012;28:312-319.

6. Ye $\mathrm{Q}$, Wang $\mathrm{Y}$, Williams $\mathrm{K}$, Spencer $\mathrm{P}$. Characterization of photopolymerization of dentin adhesives as a function of light source and irradiance. J Biomed Mater Res B Appl Biomater 2007;80:440-446.
7. Zhang YI, Wang Y. Distinct photopolymerization efficacy on dentin of self-etch adhesives. J Dent Res 2012;91:795-799.

8. Krifka S, Spagnuolo G, Schmalz G, Schweikl H. A review of adaptive mechanisms in cell responses towards oxidative stress caused by dental resin monomers. Biomaterials 2013; 34:4555-4563.

9. Sauro S, Pashley DH, Montanari M, Chersoni S, Carvalho RM, Toledano $M$, et al.. Effect of simulated pulpal pressure on dentin permeability and adhesion of self-etch adhesives. Dent Mater 2007;23:705-713.

10. Chaves CA, Machado AL, Carlos IZ, Giampaolo ET, Pavarina AC, Vergani CE. Cytotoxicity of monomers, plasticizer and degradation byproducts released from dental hard chairside reline resins. Dent Mater 2010;26:1017-1023.

11. Huang FM, Li YC, Lee SS, Chang YC. Cytotoxicity of dentine bonding agents on human pulp cells is related to intracellular glutathione levels. Int Endod J 2010;43:1091-1097.

12. Bianchi L, Ribeiro AP, Oliveira Carrilho MR, Pashley DH, Souza Costa CA, Hebling J. Cytotoxicity of adhesive systems of different hydrophilicities on cultured odontoblast-like cells. J Biomed Mater Res B Appl Biomater 2013;101:1498-1507.

13. Van Meerbeek B, Yoshihara K, Yoshida Y, Mine A, De Munck J, Van Landuyt KL. State of the art of self-etch adhesives. Dent Mater 2011;27:17-28.

14. Aranha AM, Giro EM, Souza PP, Hebling J, de Souza Costa CA. Effect of curing regime on the cytotoxicity of resin-modified glass-ionomer lining cements applied to an odontoblast-cell line. Dent Mater 2006;22:864-869.

15. Volk J, Ziemann C, Leyhausen G, GeurtsenW. Non-irradiated campherquinone induces DNA damage in human gingival fibroblasts. Dent Mater 2009;25:1556-1563.

16. Volk J, Leyhausen G, Wessels M, Geurtsen W. Reduced glutathione prevents camphorquinone-induced apoptosis in human oral keratinocytes. Dent Mater 2014;30:215-226.

17. Bølling AK, Samuelsen JT, Morisbak E, Ansteinsson V, Becher R, Dahl

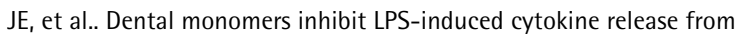
the macrophage cell line RAW264.7. Toxicol Lett 2013;216:130-138.

18. Chang MC, Chen $\mathrm{LI}$, Chan $\mathrm{CP}$, Lee JJ, Wang TM, Yang $\mathrm{T}$, et al.. The role of reactive oxygen species and hemeoxygenase- 1 expression in the cytotoxicity, cell cycle alteration and apoptosis of dental pulp cells induced by BisGMA. Biomaterials 2010;31:8164-8171.

19. Li YC, Kuan YH, Huang FM, Chang YC. The role of DNA damage and caspase activation in cytotoxicity and genotoxicity of macrophages induced by bisphenol-A-glycidyldimethacrylate. Int Endod J 2012;45:499-507.

20. Moreira F do C, Antoniosi Filho NR, Souza JB, Lopes LG. Sorption, solubility and residual monomers of a dental adhesive cured by diferent light-curing units. Braz Dent J 2010;21:432-438.

21. Ortengren $\mathrm{U}$, Wellendorf $\mathrm{H}$, Karlsson $\mathrm{S}$, Ruyter IE. Water sorption and solubility of dental composites and identification of monomers released in an aqueous environment. J Oral Rehabil 2001;28:1106-1115.

22. Spagnuolo G, Mauro C, Leonardi A, Santillo M, Paternò R, Schweikl H, et al.. NF-kappaB protection against apoptosis induced by HEMA. J Dent Res 2004;83:837-842.

23. Spagnuolo G, D'Antò V, Cosentino C, Schmalz G, Schweikl H, Rengo $\mathrm{S}$. Effect of $\mathrm{N}$-acetyl-L-cysteine on ROS production and cell death caused by HEMA in human primary gingival fibroblasts. Biomaterials 2006;27:1803-1809.

24. Costa $C A$, Mesas $A N$, Hebling J. Pulp response to direct capping with an adhesive system. Am J Dent 2000;13:81-87.

25. Costa CA, Oliveira MF, Giro EM, Hebling J. Biocompatibility of resinbased materials used as pulp-capping agents. Int Endod J 2003;36:831839. 